\title{
Two Other Important Indicators for the Assessment of Eco Dwelling*
}

\author{
Shpresa Caslli1\#, Elfrida Shehu2, Dervish Elezi1 \\ ${ }^{1}$ Department of Production and Management at Mechanical Engineering Faculty, Polytechnic University of \\ Tirana, Tirana, Albania \\ ${ }^{2}$ Department of Civil Engineering at Civil Engineering Faculty, Polytechnic University of Tirana, Tirana, Albania \\ Email: "shcaslli@fim.edu.al
}

Received 17 January 2014; revised 17 February 2014; accepted 3 March 2014

Copyright (C) 2014 by authors and Scientific Research Publishing Inc.

This work is licensed under the Creative Commons Attribution International License (CC BY). http://creativecommons.org/licenses/by/4.0/

(c) (i) Open Access

\begin{abstract}
The authors of this paper propose a practical way to assess the environmental and financial costs of the performance of a real engineering activity for the case of a dwelling/building. This estimation is based on two indicators: Energy consumption during the Life Cycle of the building, $\mathrm{E}_{\mathrm{c}} \mathrm{LC}$ and Equivalent Uniform Annual Cost, EUAC, related in various ways within the Building Life Cycle. The first indicator is determined by the Material Selection Method (CES Eco-Selector Software). While second indicator, EUAC, is determined by means of the Method of Life Cycle Cost. Consideration of these indicators from the conceptual phase of the object (dwelling), minimizes the costs of implementation and usage of the dwelling while respecting the principles of environment sustainable development. A dwelling as a product may have an environmental label, containing these two environmental and financial indicators, determined to take into account the entire life cycle. Results confirm the validity of some of the most innovative technologies currently applied in buildings and support our proposal on their energy label change.
\end{abstract}

\section{Keywords}

Eco-Design; Eco-Audit; Eco-Dwelling; EcLC; EUAC

\section{Introduction}

The ecological classification of buildings is currently based on energy consumption (mainly for heating/coolingventilation) during their use. The engineering world is looking for the implementation of engineering products/

\footnotetext{
*There are two indicators, ecological and financial ones, which help to assess how Eco a building is throughout its life cycle. ${ }^{\#}$ Corresponding author.
} 
objects projects, required to be more environmentally friendly and to ensure its durability and sustainability throughout their life cycle.

To reduce the environmental impact each product should reduce the usage of: 1) non-renewable resources of energy and materials; 2) energy during the fabrication; 3) fuel for transport; 4) energy to preserve, to maintain or to use the products/objects [1].

Nowadays, the market requires competitive and fast solutions to the first phase of conception of the problem design that protect the environment. Products/objects in the environment that surround us are made out of materials. The presence of extremely large number of material brands and their properties and attributes has led to the creation of databases of materials and processes as well as the computerized selection programs. CES EduPack 2012 software (CES-Cambridge Engineering Selector) is used in this paper. This program contains several databases: Level 1, 2 and 3; Architecture; Biomaterials; Polymers; Eco Design; etc. [2]. Each of databases has relevant tables, as: Materials, Processes, etc. Records in each table amounts to thousands, while attributes and properties of a record are in the tens. In the list of attributes, along with the general, physical, mechanical, thermal, electrical ones, etc., are also added to the Eco-Attributes as: Embodied energy, primary production (MJ/kg); $\mathrm{CO}_{2}$ footprint, primary production $(\mathrm{kg} / \mathrm{kg}) ; \mathrm{NO}_{\mathrm{x}}$ creation $(\mathrm{g} / \mathrm{kg})$; $\mathrm{SO}_{\mathrm{x}}$ creation $(\mathrm{g} / \mathrm{kg})$; Water usage $(\mathrm{l} / \mathrm{kg})$; Recycle Fraction (\%), Annual World Production (ton/year).

Eco selection method aims to find the environmental impact of product in the conceptual phase first point of design. For this CES EduPack 2012 along with Eco-Attributes also contains the Eco-Audit Tool that uses these attributes in the material selection. The Results of Eco Audit are expressed through a significant stressor for the environment (environmental indicator), the Energy consumption throughout the product Life Cycle, $E_{c} L C$, which can be converted in $\mathrm{CO}_{2}$ footprint that released into the atmosphere during the product life [1] [3] [4].

Based on another method of Life Cycle Cost (LCC) is calculated the financial cost of the product over its lifespan and that it's determined by the indicator: EUAC, Equivalent Uniform Annual Cost.

This paper aims to compare Traditional dwelling designs with Eco dwelling on the bases of two indicators: $\mathrm{E}_{\mathrm{C}} \mathrm{LC}$ and EUAC and suggest their involvement as practical criteria for ecological dwelling classification in an "ecological-financial label".

\section{The Methods}

\subsection{Eco-Design Method Based on the Material Selection and the Indicator " $E_{c} L C-E n e r g y$ Consumption throughout the Life Cycle"}

Eco design approach is computationally incorporated in the CES software. Eco Audit tool processes data (inputs) for each of the components that made up the product [4] [5]. Later, the tool "retrieves" or drawn the data for embodied energies (first production) and processing energies from a database of material properties or processes, multiples it with the component mass (for first phase of life cycle-Material). These data are related to ecoattributes and Eco audit tool calculates the amount of energy for the 5 phases of the life cycle of product.

The outputs of Eco audit are the energy or carbon footprint of each phase of life, presented as bar chart and in tabular form [2]. Figure 1 shows the structure of the tool.

The outputs of Eco audit enables to distinguish the phase of life that consumes more energy or releases more carbon in atmosphere and to focus on the selection of those materials, processes, forms of transport, the usage or product disposal forms at the end of life that reduce the amount of consumed energies. Consequently the burden of energy at that phase and the total energy consumption are reduced [4] [5].

\subsection{Life Cycle Cost Method and EUAC Indicator, Equivalent Uniform Annual Cost}

Besides the environmental impact, every engineering project is accompanied by financial costs (let say: financial impact). Which are the financial costs for the insulated dwelling? It is assumed that eco-dwelling is more expensive, but how true is that? To answer this question we use the Life Cycle Cost Method. According to this method, the calculation is based not only on the initial costs, but on the cost of whole life cycle, which include investments cost, maintenance costs and operating costs [6].

EUAC indicator will be used to compare two variants, the traditional dwelling to dwelling with eco building elements, from financial of view. It is required that all values of the allocated costs in time are converted in an annual value, constant or uniform throughout the lifetime of building. 


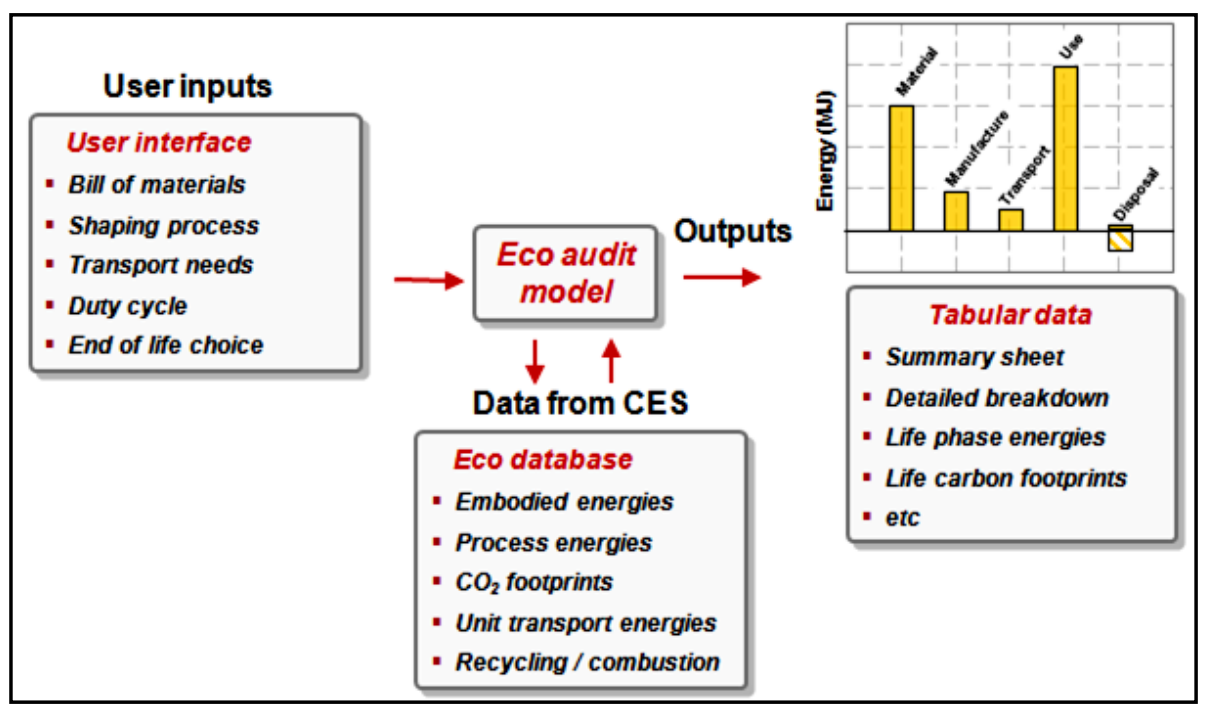

Figure 1. The Eco audit model combines user-defined inputs with data drawn from databases of embodied energy of materials, processing energies, and transport type to create the energy breakdown. The same tool can be used for an assessment of $\mathrm{CO}_{2}$ footprint [5].

$$
\mathrm{EUAC}=f(C i, i, n)[7]
$$

where:

$\mathrm{Ci}=$ cost by the moment of their application;

$i=$ annual interest rate (\%);

$n=$ service life (years).

In simple terms, EUAC is the "payment" required to fund the Life Cycle Cost over the service life. This "payment" is calculated using the same principles as mortgage financing. The Life Cycle Cost represents the "purchase price” and EUAC represents "mortgage payment” needed for a given interest rates to fully fund the Life Cycle Cost by the end of the started service life [7].

Because EUAC costs are stated as an annualized amount, it becomes possible to compare directly two variants of dwelling.

The determination of EUAC based on:

- Initial and service life costs;

- Traditional dwelling and insulation life expectancy;

- The rate of interest to be used to perform movements of capital at the time.

\section{Results}

\subsection{Determination of the Energy Consumption during the Life Cycle of the Building, $E_{c} L C$}

\subsubsection{Determination of Energy Consumption in the Case of Traditional Dwelling}

Applying the Eco Audit tool initially for two storey villas (Figure 2), according to the bill of materials by traditional design (Table 1). This villa/dwelling contains four apartments and it's designed to use for weekends and summer holidays from four families.

The inputs are typing in the Eco Audit Tool interface. Initially data is the bill of product components that comprise a two storey dwelling: the first box of Table 1 contain the component name; the second box contain its material that is chosen from the pull-down menu of CES database of materials properties: Selecting a material from the tree-like hierarchy of materials causes the tool to retrieve (drawn) and store its embodied energy and $\mathrm{CO}_{2}$ footprint per kg; next to it we can type the quantities of materials, in mass, $\mathrm{kg}$.

Primary shaping process is chosen from the pull-down menu of third box in interface, which lists the processes relevant for the chosen material; the tool again retrieves process energy and its carbon footprint per kg. On completing a row-entry a new row appears for the next component. Here we show only the data for the first phase of the materials. In Eco Audit Tool interface we have typed data on fabrication, transport, use (energy 


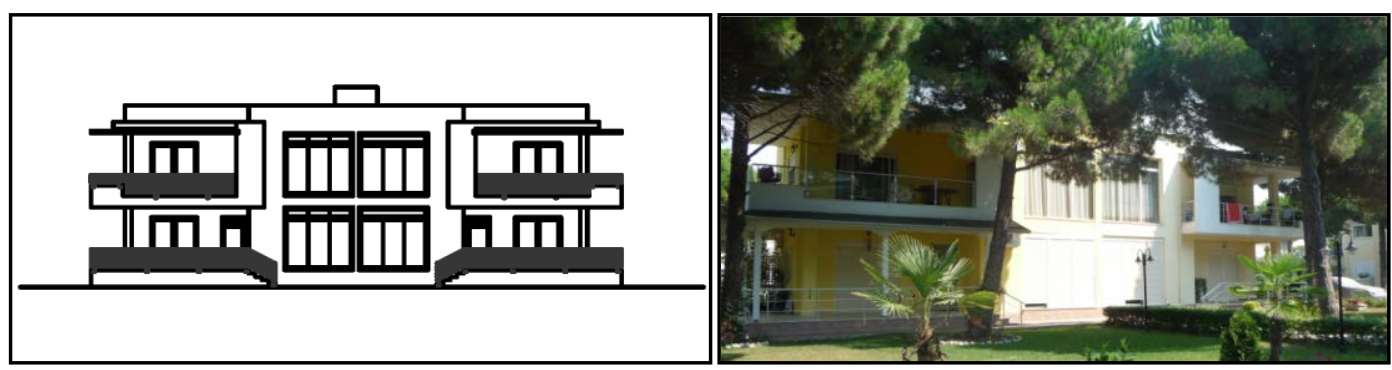

Figure 2. Two-storey villas in the central coastal area, built according to a traditional design; it's estimated with longevity about 50 years.

Table 1. Energy data of first phase of life, Materials for the dwelling components materials [2].

\begin{tabular}{|c|c|c|c|c|c|c|c|}
\hline Component & Material & $\begin{array}{l}\text { Part mass } \\
\quad(\mathrm{kg})\end{array}$ & $\begin{array}{c}\text { Total mass } \\
\text { processed (kg) }\end{array}$ & $\begin{array}{l}\text { Energy } \\
\text { (MJ) }\end{array}$ & $\%$ & $\begin{array}{l}\mathrm{CO}_{2} \text { footprint } \\
(\mathrm{kg})\end{array}$ & $\%$ \\
\hline Stone Foundation & Granite (2.63) & $2.2 \mathrm{e}+05$ & $2.4 \mathrm{e}+05$ & $1.4 \mathrm{e}+06$ & 37.9 & $7.8 \mathrm{e}+04$ & 28.4 \\
\hline Masonry & Brick (common, hard) (2.25) & $2.1 \mathrm{e}+05$ & $2.1 \mathrm{e}+05$ & $7 e+05$ & 18.3 & $4.6 \mathrm{e}+04$ & 16.7 \\
\hline Column & Concrete (normal (Portland cement)) & $3.7 \mathrm{e}+05$ & $3.7 \mathrm{e}+05$ & $4.2 \mathrm{e}+05$ & 11.0 & $3.5 \mathrm{e}+04$ & 12.8 \\
\hline Reinforced concrete & Carbon steel, AISI 1020, as rolled & $1.2 \mathrm{e}+04$ & $1.2 \mathrm{e}+04$ & $3 e+05$ & 7.9 & $2.1 \mathrm{e}+04$ & 7.6 \\
\hline Floor & Ceramic tile & $3 e+04$ & $3 e+04$ & $3.6 \mathrm{e}+05$ & 9.4 & $5 e+04$ & 18.3 \\
\hline Plaster & Plaster of paris & $8.6 \mathrm{e}+04$ & $8.6 \mathrm{e}+04$ & $1.9 \mathrm{e}+05$ & 5.0 & $1.7 \mathrm{e}+04$ & 6.2 \\
\hline $\begin{array}{l}\text { Windows, } \\
\text { doors flames }\end{array}$ & $\begin{array}{l}\text { Aluminum, commercial purity, } \\
1050 \mathrm{~A} \text {, wrought, H9 }\end{array}$ & $9.1 \mathrm{e}+02$ & $9.1 \mathrm{e}+02$ & $1.9 \mathrm{e}+05$ & 5.0 & $1.1 \mathrm{e}+04$ & 4.2 \\
\hline Windows & Soda lime-0080 & $2.1 \mathrm{e}+02$ & $2.3 e+02$ & $2.4 \mathrm{e}+03$ & 0.1 & $1.7 \mathrm{e}+02$ & 0.1 \\
\hline Doors & Oak (quercus alba) (l) & $1 \mathrm{e}+03$ & $1.2 \mathrm{e}+03$ & $1.2 \mathrm{e}+04$ & 0.3 & $1 \mathrm{e}+03$ & 0.4 \\
\hline Hydraulic plumbing & $\begin{array}{l}\text { Copper, C14200, wrought, soft } \\
\text { (tough-pitch arsenical h.c. copper) }\end{array}$ & $1.7 \mathrm{e}+02$ & $1.7 \mathrm{e}+02$ & $9.9 e+03$ & 0.3 & $6.2 \mathrm{e}+02$ & 0.2 \\
\hline Pipes & PVC (semi-rigid, molding and extrusion) & $1.3 \mathrm{e}+02$ & $1.3 \mathrm{e}+02$ & $7.5 \mathrm{e}+03$ & 0.2 & $3.2 \mathrm{e}+02$ & 0.1 \\
\hline $\begin{array}{l}\text { Electrical conductors: } \\
\text { cable core }\end{array}$ & $\begin{array}{l}\text { Copper-cadmium alloy, C16200, } \\
\text { wrought, soft (h.c. copper) }\end{array}$ & $5.4 \mathrm{e}+02$ & $5.6 e+02$ & $3.2 \mathrm{e}+04$ & 0.8 & $2 \mathrm{e}+03$ & 0.7 \\
\hline Cable sheath & PVC/PMMA (unfilled) & 68 & 72 & $8.3 e+03$ & 0.2 & $4.7 \mathrm{e}+02$ & 0.2 \\
\hline Terrace-roof & Concrete (structural lightweight) & $1.2 \mathrm{e}+05$ & $1.2 \mathrm{e}+05$ & $1.4 \mathrm{e}+05$ & 3.6 & $1.1 \mathrm{e}+04$ & 4.2 \\
\hline Total & & & $1.1 \mathrm{e}+06$ & $3.8 e+06$ & 100 & $2.7 e+05$ & 100 \\
\hline
\end{tabular}

sources associated with use-Figure 3 ) and disposal of materials. The tool multiplies the energy and $\mathrm{CO}_{2}$ per $\mathrm{kg}$ of each component by its mass and totals them.

Needed some data for Use phase of dwelling: Annual average consume of electric energy for an Albanian family is about $5000 \mathrm{~kW} / \mathrm{h}$ [8]; need for energy that is consumed for heating/cooling is $60 \%$ [8], so, $5000 \times 60 \%$ $=3000 \mathrm{kWh}: 200$ days per year (usage of dwelling) $=15 \mathrm{kWh} /$ day. Average electricity used for about 8 hours. Then, $15 \mathrm{kWh}: 8 \mathrm{~h}=1875 \mathrm{~kW}$. In building lives four families (or there are 4 apartments), therefore "Power rating” would be: $1875 \times 4=7.5 \mathrm{~kW}$ [2].

Eco Audit tool generates the outputs that are the energy or carbon footprint of each phase of life, which is presented as bar chart or in tabular form. It can be clearly distinguished that the greatest consumed energy in the traditional dwelling goes in the first phase, the Materials, and fourth phase in the Use of the dwelling. Detailed report we can see in following (Figure 4 and Table 2).

So, it’s calculated the Energy consumption throughout the Life Cycle for a without insulation dwelling (1): 


$$
E c L C_{\text {without insulation }}=\frac{\text { Total Energy }}{\text { surface } \times \text { years }}=\frac{7.4 \times 10^{6} \mathrm{MJ}}{480 \mathrm{~m}^{2} \times 50 \text { years }}=308 \frac{\mathrm{MJ}}{\mathrm{m}^{2} \text { years }}
$$

\begin{tabular}{|c|c|c|c|}
\hline \multicolumn{4}{|l|}{ Joining and finishing } \\
\hline Name & Process & Amount & Unit \\
\hline Walls & Painting & 3405 & $m^{\wedge} 2$ \\
\hline Building & Construction & $1,016 \mathrm{e}+06$ & $\mathrm{~kg}$ \\
\hline Hydraulic plumbing & Fasteners, small & 30 & \\
\hline Floor & Adhesives, cold curing & 376 & $m^{\wedge} 2$ \\
\hline
\end{tabular}

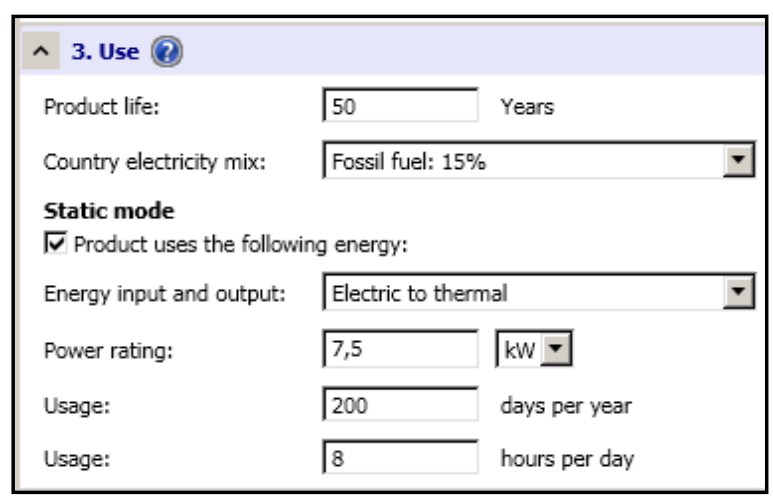

Figure 3. A part of user interface for the data of Fabrication and Use phase.

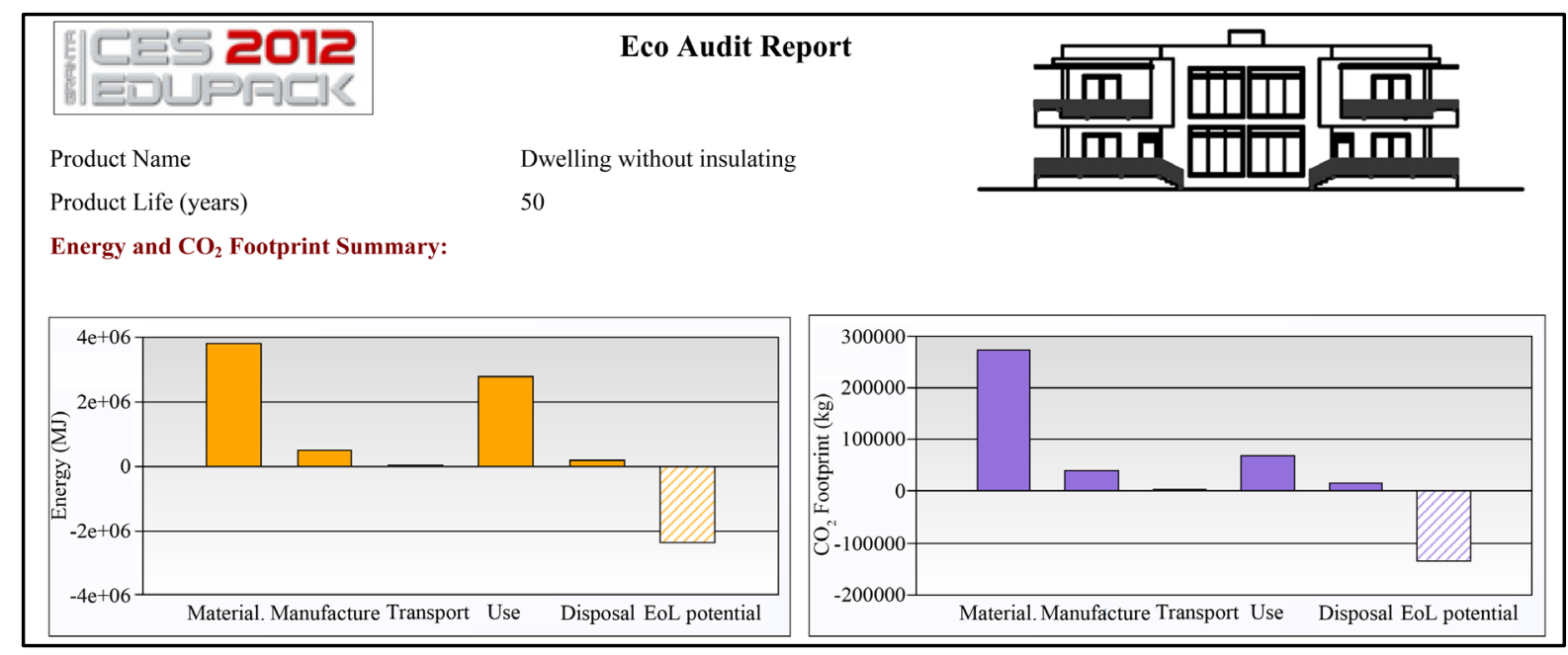

Figure 4. A part of Eco Audit Report generated from software [2].

Table 2. The Eco Audit results for energy and $\mathrm{CO}_{2}$ footprint for the five life phases (in 50 years lifespan), for a dwelling without thermo insulation [2].

\begin{tabular}{ccccc}
\hline Phase & Energy (MJ) & Energy (\%) & $\mathbf{C O}_{2}(\mathbf{k g})$ & $\mathbf{C O}_{\mathbf{2}}(\mathbf{\%})$ \\
Material & $3.82 \mathrm{e}+06$ & 51.6 & $2.74 \mathrm{e}+05$ & 68.4 \\
Manufacture & $5.19 \mathrm{e}+05$ & 7.0 & $3.96 \mathrm{e}+04$ & 9.9 \\
Transport & $4.46 \mathrm{e}+04$ & 0.6 & $3.17 \mathrm{e}+03$ & 0.8 \\
Use & $\mathbf{2 . 8 1 e + 0 6}$ & 37.9 & $6.91 \mathrm{e}+04$ & 17.3 \\
Disposal & $2.11 \mathrm{e}+05$ & 2.8 & $1.48 \mathrm{e}+04$ & 3.7 \\
Total (for first life) & $\mathbf{7 . 4 e + 0 6}$ & $\mathbf{1 0 0}$ & $\mathbf{4 e}+\mathbf{0 5}$ & $\mathbf{1 0 0}$ \\
\hline
\end{tabular}




\subsubsection{The Determination of the Consumed Energy (or Saved Energy) for the Eco Dwelling}

According to Eco-design strategy, we must focus exactly on the two life phases with the highest energy consumption [1] [4] [5]. To reduce the amount of energy during the aforementioned phases, when the dwellings are built according to a traditional design, select the materials with low embodies energy (to reduce the energy in Material phase) and low thermal conductivity (to reduce the energy in Use phase). The selection of these materials is done according to the chart: "Thermal conductivity versus embodies energy" [2], by help of box selection (red rectangle), which is requiring candidates with the lowest value of these properties (Figure 5). In our case, when the current dwelling is already built, focus on finding of insulating materials that serve as external layer of walls, to ensure reducing of energy consumption during Use phase. In figure below (under selection chart) is zoomed a part of its, records inside the box selection.
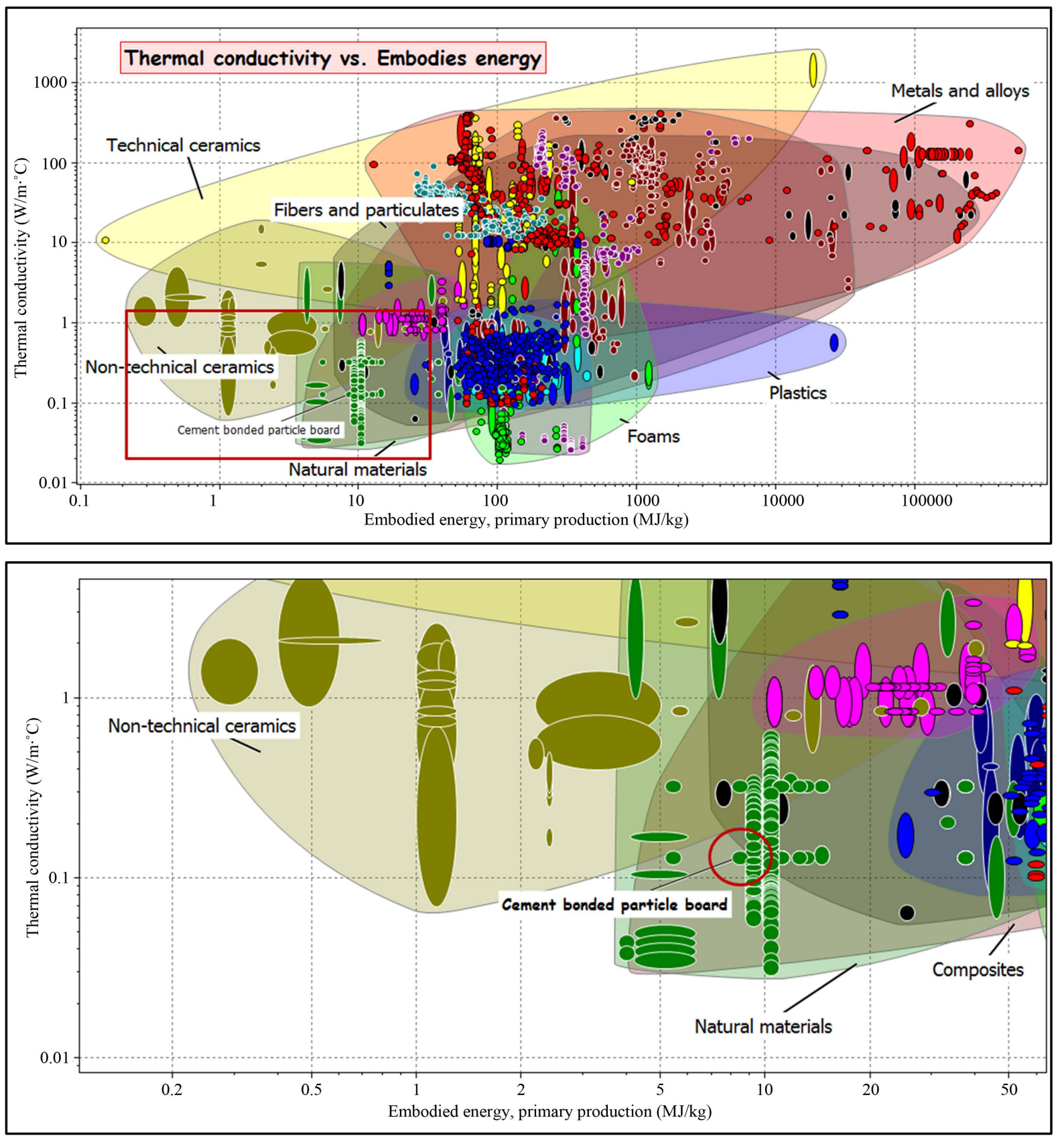

Figure 5. The chart of material selection with low thermal conductivity and low embodies energy [2]. 
Such process leads us to the selection of BETOPAN, a cement matrix composite, reinforced with wood chips (particles), and otherwise called "Cement bonded particle board" (red circle in Figure 5). BETOPAN is a good thermo-isolating material; its thermal conductivity coefficient, $\lambda=0.12-0.15 \mathrm{~W} / \mathrm{m}^{\circ} \mathrm{C}$. It has been manufactured since 1984 and it has become the favorite product of the building construction sector. It consists of a mixture of wood, cement and harmless chemical additives. It gets its lightness, flexibility and treatability from wood, and its waterproof, moisture-proof and its resistance to fire and deterioration from cement. BETOPAN is offered to consumers with superior constructive characteristics [9].

Let's look at the energy balances when the outer walls $(25 \mathrm{~cm})$ of the two-storey villa $\left(2 \times 240 \mathrm{~m}^{2}\right)$ are thermo insulated with BETOPAN plates, with a $30 \mathrm{~mm}$ thickness (considering the climatic-geographic area location of the dwelling). Table 3 summarizes the data generated by the Eco Audit on thermo-isolating material and the results of the energy consumption during the "Materials" phase (in this Table are missing other components of dwelling, which are included in Table 1).

To determine how the energy columns change during the usage phase, we can pursue two options:

- Calculating energy losses through the walls, windows and doors in the case with thermo insulation. These energy losses will serve to calculate the "Power rating" when the dwelling is thermo-insulated. Our calculations are focused on the loss of electrical energy for heating/ventilation of the apartment.

- Applying again the Eco Audit tool, after the inclusion of additional new material, as thermo insulator of exterior walls and compare it with energy bar chart of without insulating dwelling case (Figure 6).

1) Electrical energy losses during the heating-ventilation of a non-thermoinsulated dwelling.

When the dwelling is without thermo insulation, all elements that constitute its enclosure are without insulation: walls, windows and doors ( $353.05 \mathrm{~m}^{2}$ walls $+85 \mathrm{~m}^{2}$ windows, doors $=438 \mathrm{~m}^{2}$ in total); terrace roof (240 $\mathrm{m}^{2}$ ) and ground floor $\left(240 \mathrm{~m}^{2}\right)$. Total energy losses are divided between external walls, about 35\%; windows and doors, about $15 \%$; terrace roof, about $25 \%$; ground floor, about $15 \%$ and others $10 \%$ [8]. From the results in Table 2 energy consumption during 50 years of Use phase will be about $2.81 \times 10^{6} \mathrm{MJ}$ and in total $7.4 \times 10^{6} \mathrm{MJ}$. Brunt of energy losses makes up heat/ventilation energy losses from walls (Figure 6, left), windows and doors. An eco design aims to reduce these energy losses.

2) Energy loss in the dwelling with thermo insulation walls, windows and doors.

Based on scheme of Figure 6, right and formula [10] it is calculated $Q_{\text {Annual }}-$ Annual energy losses through insulated walls, taking $\lambda_{\text {BETOPAN }}=0.15 \mathrm{~W} / \mathrm{m}^{\circ} \mathrm{C}$ of thermo insulation layer and douple glasses $\left(\lambda_{\text {DOUPLE GLASSES }}=\right.$ $3.6 \mathrm{~W} / \mathrm{m}^{\circ} \mathrm{C}$ ), resulting:

$$
Q_{\text {annual insulated walls, windows, doors }}=2764 \mathrm{kWh} \text {. }
$$

Table 3. Energy data and $\mathrm{CO}_{2}$ footprint for BETOPAN plates that are used to coat exterior walls [2].

\begin{tabular}{|c|c|c|c|c|c|c|c|}
\hline Component & Material & Part mass (kg) & $\begin{array}{c}\text { Total mass } \\
\text { processed }(\mathbf{k g})\end{array}$ & Energy (MJ) & $\%$ & $\underset{\text { (kg) }}{\mathrm{CO}_{2} \text { footprint }}$ & $\%$ \\
\hline $\begin{array}{c}\text { Insulating } \\
\text { layer-BETOPAN }\end{array}$ & $\begin{array}{l}\text { Cement bonded particle board, } \\
\text { perpendicular to board }\end{array}$ & $1.4 \mathrm{e}+04$ & $1.4 \mathrm{e}+04$ & $1.2 \mathrm{e}+05$ & 3.0 & $8.7 e+03$ & 3.1 \\
\hline
\end{tabular}

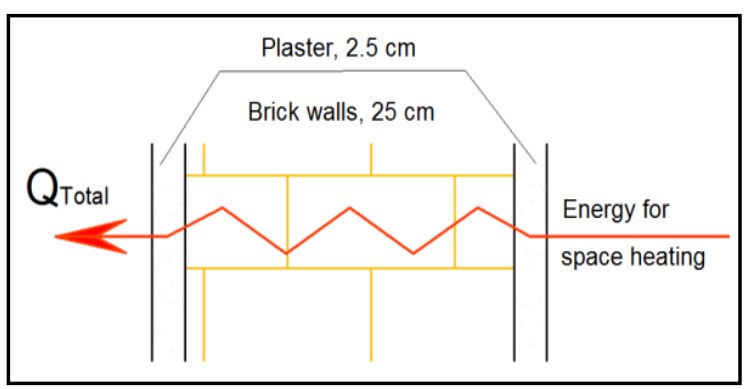

(a)

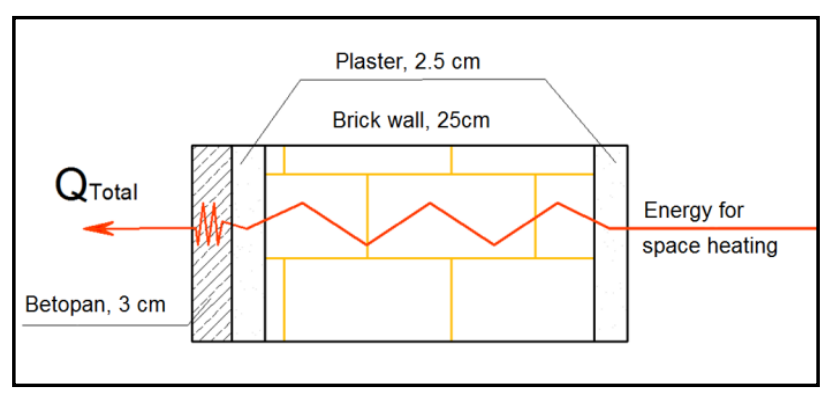

(b)

Figure 6. Scheme of energy loss through walls without and with thermoisolation. (a) Total energy losses when wall are without thermo insulation; (b) Total energy losses when wall are with thermo insulation. 
Dwelling with thermo insulation during a year lost energy through walls, windows and doors: $2764 \mathrm{kWh}: 200$ days per year: $8 \mathrm{~h}=\mathbf{1 . 7} \mathrm{kW}$, that is "Power rating" after thermo insulation of walls, windows and doors.

The results of Eco Audit Report are presented in summary chart (Figure 7) and Table 4:

3) The energy saving or the reducing of the column during the using phase, which comes from the thermo insulation.

Total annual savings from the thermo insulation of walls, windows and doors in Use phase are:

$$
2.81 \times 10^{6}-6.36 \times 10^{5}=\mathbf{2 . 1 7} \times \mathbf{1 0}^{6} \mathrm{MJ} ;
$$

In total, saved energy throughout life cycle is $\mathbf{2 . 0 4} \times \mathbf{1 0}^{6} \mathrm{MJ}\left(7.4 \times 10^{6}-5.36 \times 10^{6}\right)$.

Bar charts of energy and $\mathrm{CO}_{2}$ footprint and Table 4 present these results in summarized form, while the histograms in Figure 8 compare results of a dwelling with and without thermo insulation:

The energy saving of the thermo insulation dwelling is reduced by $\mathbf{2 8 \%}$ less in comparison to the without thermo insulation dwelling, when only walls, windows and doors are insulated.
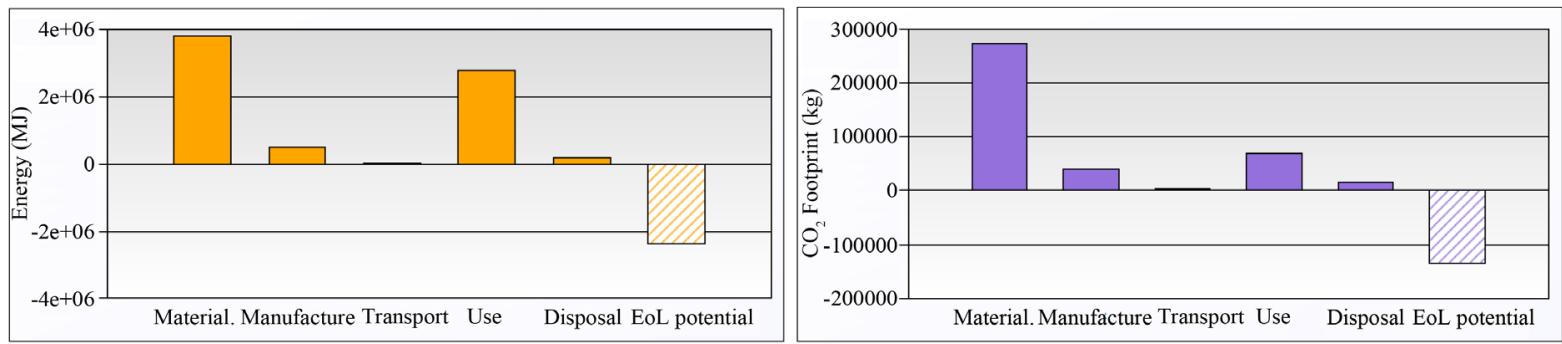

Figure 7. Summary charts for thermo insulation dwelling.

Table 4. The results of Eco Audit for the energy and the footprint of $\mathrm{CO}_{2}$ for the thermo insulated dwelling [2].

\begin{tabular}{ccccc}
\hline Phase & Energy (MJ) & Energy (\%) & $\mathbf{C O}_{\mathbf{2}} \mathbf{( k g )}$ & $\mathbf{C O}_{2}(\mathbf{\%})$ \\
\hline Material & $3.93 \mathrm{e}+06$ & 73.4 & $2.82 \mathrm{e}+05$ & 78.8 \\
Manufacture & $5.33 \mathrm{e}+05$ & 9.9 & $4.23 \mathrm{e}+04$ & 11.8 \\
Transport & $4.52 \mathrm{e}+04$ & 0.8 & $3.21 \mathrm{e}+03$ & 0.9 \\
Use & $\mathbf{6 . 3 6 e + 0 5}$ & 11.9 & $1.57 \mathrm{e}+04$ & 4.4 \\
Disposal & $2.13 \mathrm{e}+05$ & 4.0 & $1.49 \mathrm{e}+04$ & 4.2 \\
Total (for first life) & $5.36 \mathrm{e}+\mathbf{0 6}$ & $\mathbf{1 0 0}$ & $\mathbf{3 . 5 8 e + 0 5}$ & $\mathbf{1 0 0}$
\end{tabular}
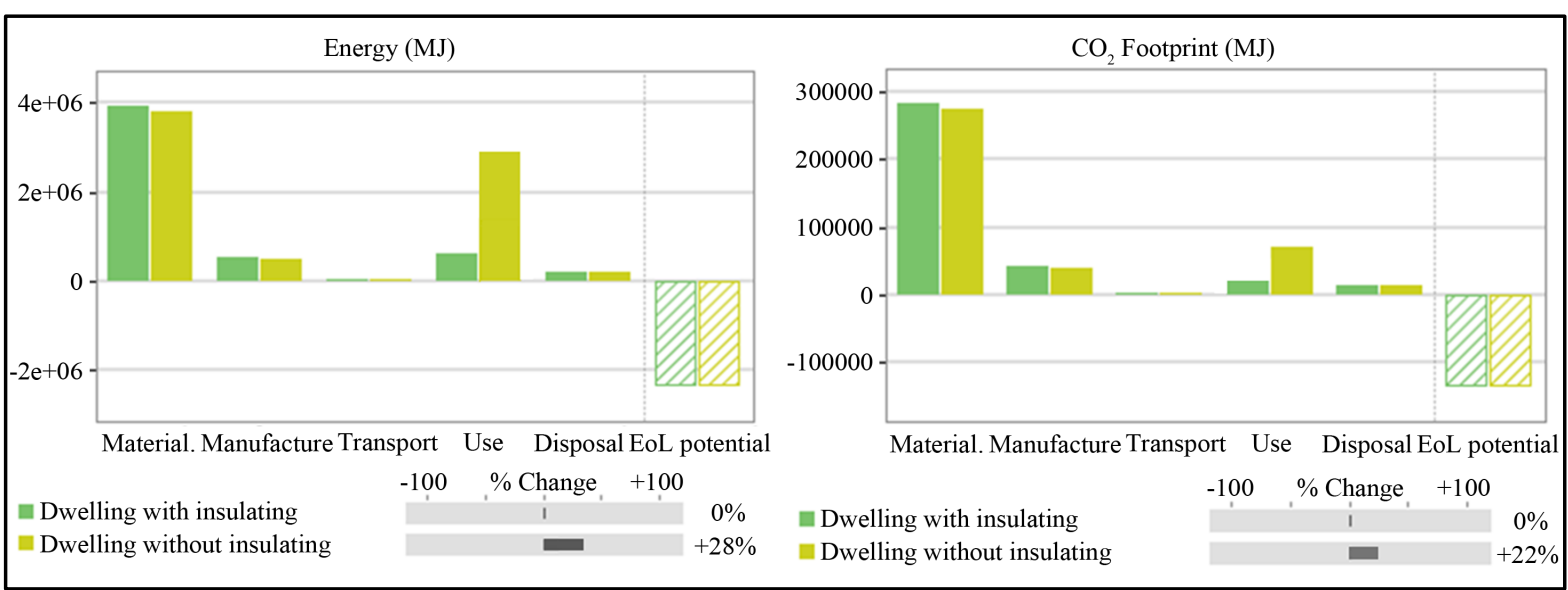

Figure 8. Comparison of the results of the Eco Audit for both types of dwellings [2]. 
Histogram graphs clearly show the changing of environmental effect, expressed by the reduction of consumed energy indicators in the fourth phase, and in particular, the total energy consumption in the designed dwelling by the eco principle versus the traditional dwelling (2).

$$
E_{c} L C_{\text {with insulation }}=\frac{\text { Total Energy }}{\text { surface } \times \text { years }}=\frac{5.36 \times 10^{6} \mathrm{MJ}}{480 \mathrm{~m}^{2} \times 50 \text { years }}=223 \frac{\mathrm{MJ}}{\mathrm{m}^{2} \text { years }}
$$

\subsection{Determination of the Equivalent Uniform Annual Cost (EUAC Indicator) for the Traditional and Eco Dwelling}

\subsubsection{Initial Cost}

Initial cost, or traditional dwelling construction cost is determined by synthetic methods. Through comparison with other similar objects, which according to researchers conducted in the area where the villas is located, as the object of study, cost about 25,000 ALL/ $\mathrm{m}^{2}$. As the villas are built with 2 floors and each floor has an area of $240 \mathrm{~m}^{2}$, the value of building traditional villas is:

$$
240 \mathrm{~m}^{2} \times 2 \times 25,000 \mathrm{ALL} / \mathrm{m}^{2}=12,000,000 \mathrm{ALL} .
$$

The cost of insulation with BETOPAN, including purchases of materials and assembling in flat of BETOPAN plates, is $2550 \mathrm{ALL} / \mathrm{m}^{2}$ [11].

Surface outside wearing BETOPAN: $353.05 \mathrm{~m}^{2} \times 2550 \mathrm{ALL} / \mathrm{m}^{2}=900277.5$ ALL (ALL: ALBANIAN LEK).

\subsubsection{The Annual Cost}

- Maintenance costs are different and vary depending on the care that is indicated for the building. They can be expressed as a percentage of the initial cost, about $0.5 \%$ [6].

- Costs for heating, etc. Environmental impact calculations were concluded that savings in energy consumption for thermal insulation effect are $\mathbf{2 . 0 4} \times \mathbf{1 0}^{\mathbf{6}} \mathrm{MJ}$ : 3.6: 50 years $=\mathbf{1 1 , 3 3 3} \mathrm{kWh} / \mathrm{year}$.

\subsubsection{Replacement Cost}

Replacement cost includes not only the initial cost, but also the costs of the removal of part/parts that will be replaced. These costs are estimated approximately $4 \%$ of the initial cost.

\subsubsection{Service Life}

Since we are dealing with an object on the coast, traditional building durability is expected to be about 50 years, while thermal insulation durability of exterior walls with BETOPAN is projected to be 20 years [12]. Thus insulation is required to be renewed after 20 years. The results of the calculations are summarized in Table 5.

It's calculated EUAC indicator, using annual interest rate of 4.5\% (respective without (3) and with insulation (4)).

$$
\begin{aligned}
& \text { EUAC }_{\text {without insulation }} \\
& =12,000,000 \frac{(1+0.045)^{50} \times 0.045}{(1+0.045)^{50}-1}+60,000+480,000 \frac{0.045}{(1+0.045)^{50}-1}+198,432 \\
& =868,347 \mathrm{ALL} / \text { year } \\
& \quad \text { EUAC }_{\text {with insulation }} \\
& =120,000,000 \frac{(1+0.045)^{50} \times 0.045}{(1+0.045)^{50}-1}+60,000+480,000 \frac{0.045}{(1+0.045)^{50}-1} \\
& \quad+900,278 \frac{(1+0.045)^{20} \times 0.045}{(1+0.045)^{20}-1}+4501+36,011 \frac{0.045}{(1+0.045)^{20}-1}+32,645 \\
& =777,419 \mathrm{ALL} / \text { year }
\end{aligned}
$$


Table 5. Results of Life Cycle Cost and EUAC indicator for two types of dwellings.

\begin{tabular}{ccccccc}
\hline & Service life (years) & $\begin{array}{c}\text { Initial Cost, } \\
\text { (ALL) }\end{array}$ & $\begin{array}{c}\text { Maintenance } \\
\text { Cost, (ALL) }\end{array}$ & $\begin{array}{c}\text { Replacement } \\
\text { Cost, (ALL) }\end{array}$ & $\begin{array}{c}\text { Energy consumed } \\
\text { in year, (ALL) }\end{array}$ & $\begin{array}{c}\text { EUAC, } \\
(\text { ALL/m².year) }\end{array}$ \\
\hline $\begin{array}{c}\text { Traditional dwelling } \\
\begin{array}{c}\text { Thermo insulated } \\
\text { dwelling }\end{array}\end{array}$ & $\begin{array}{c}\text { 50-building } \\
\text { 20-thermo insulated layer }\end{array}$ & $12,000,000$ & 60,000 & $12,480,000$ & 198,432 & $\mathbf{1 8 0 , 9 0 6}$ \\
\hline
\end{tabular}

\section{Discussion}

Traditional dwellings are those buildings which have been designed without taking into account the principles of environmental protection. Nowadays people are trying to find ways to return the buildings already constructed as traditional ones in buildings with eco elements. On the other hand are becoming more and more attempts to design new buildings as eco ones. Architects and Constructors aim to reduce the energy consumption during the Use phase. Walls, windows, doors, roof and ground floor may be the subject of the constructor`s scope. In our case study, the walls of a dwelling, already constructed and in use are chosen as subject to apply eco-design method.

The method of eco designs through Eco Audit tool is an interactive method that provided us the energy consumption throughout the life cycle of a product. Bar chart of a dwelling without thermo insulation is compared with bar chart of a dwelling with thermo insulation: in our case is selected a layer for external walls, with lower value of thermal conductivity and embodies energy—cement bonded particle board; double glasses for windows and doors. The designer may choose another record with better performance than the first insulator and apply in software with the data of new record (new insulator layer), which generates another bar chart of energy consumption all over life cycle (for dwelling with thermo insulation walls) that will be compared with previous. The winner insulation layer will be the one that provides the lowest environmental stressor, energy consumption during the life cycle.

When Architects and Constructors will design an eco-dwelling before it build, the selection of materials according to Eco-Selection Methods provides a list of candidates who meet the requirements of eco-design; so, they are looking for materials with low embody energy, mainly from renewable resources-that will reduce the energy consumption in first phase of life cycle, Material (results in Tables 2 and 4 show that energy consumption in this phase is high). Applying the principles of eco-design strategy for dwelling, designer aims to reducing the energy consumption during fabrication, transportation, usage and ways of disposal to obtain a dwelling with total energy consumption much lower.

After the Eco Audit Tool generates total energy consumption, the designer can calculate two important indicators: $E_{c} L C$ and EUAC, which take in consideration environmental stressor and financial costs throughout the life cycle. The authors consider the $\mathrm{E}_{\mathrm{C}} \mathrm{LC}$ indicator as a comprehensive and objective assessment of the environmental impact of dwelling, and as such should be included as a classification criterion (Figure 9). $\mathrm{E}_{\mathrm{c}} \mathrm{LC}$ indicator 1) for dwelling without thermo insulation classifies them according to category $\boldsymbol{D}: 308 \mathrm{MJ} / \mathrm{m}^{2}$ year $=$ $85.56 \mathrm{kWh} / \mathrm{m}^{2}$ year $<90 \mathrm{kWh} / \mathrm{m}^{2}$ year, while after insulation of dwelling (only external walls, windows and doors), this indicator 2) classifies it according to category $C$ : $223 \mathrm{MJ} / \mathrm{m}^{2}$ year $=61.9 \mathrm{kWh} / \mathrm{m}^{2}$ year $<70 \mathrm{kWh} /$ $\mathrm{m}^{2}$ year.

Thermo insulation of roof, ground floor or other structural elements of dwelling will improve the situation of energy consumption throughout its lifespan and this will enable the classification of dwelling in category B.

Partial results from the application of the LCC method for determining EUAC derive this indicator as an interesting one to join with $E_{c} L C$. The results of this application show a decline of EUAC from 1809.06 ALL/year in $1619.62 \mathrm{ALL} / \mathrm{year}$, not insignificant, while undoubtedly, increase in buildings eco elements will bring a greater decline in EUAC, indicative of a greater savings.

The authors believe that EUAC will be an "attractive" and "glamorous" indicator for "ecological dwelling" product users and that it would have a greater effect, compared with cycles of lectures on environmental awareness.

Several researcher who share this proposal, have a open field to determine the values range of $\mathrm{E}_{\mathrm{c}} \mathrm{LC}$ and EUAC for dwelling classes. 


\begin{tabular}{|c|c|c|c|}
\hline Energy Consumption Classes & $\begin{array}{c}\text { Energy Consumption, } \\
\mathrm{kWh} / \mathrm{m}^{2} \text {.vear }\end{array}$ & EcLC, MJ $/ \mathrm{m}^{2}$.year & EU AC, ALL/ $/ \mathrm{m}^{2}$.year \\
\hline Passive dwelling & $<15 \mathrm{kWh} / \mathrm{m}^{2}$.year & & \\
\hline A & $<30 \mathrm{kWh} / \mathrm{m}^{2}$.year & & \\
\hline 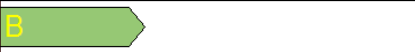 & $<50 \mathrm{kWh} / \mathrm{m}^{2}$.year & & \\
\hline$>$ & $<70 \mathrm{kWh} / \mathrm{m}^{2}$.year & now is 223 & \\
\hline$\Rightarrow$ & $<90 \mathrm{kWh} / \mathrm{m}^{2}$.year & was 308 & \\
\hline$>$ & $<120 \mathrm{kWh} / \mathrm{m}^{2}$.year & & \\
\hline $\bar{F}$ & $<160 \mathrm{kWh} / \mathrm{m}^{2}$.year & & \\
\hline G & $>160 \mathrm{kWh} / \mathrm{m}^{2}$.year & & \\
\hline
\end{tabular}

Figure 9. Dwelling ecological-financial label.

\section{Conclusions}

- Change the dwelling energitic label. The label should be named according to the eco-financial criteria based on "energy consumption throughout the product life", and also contain two evaluation criteria according to $\mathrm{E}_{\mathrm{c}} \mathrm{LC}$ and EUAC indicators.

- Even the initial cost of eco-dwelling is higher, the life cycle cost is lower because of wasted energy saved in the use phase.

\section{References}

[1] Ashby, M.F. (2009) Materials and the Environment. Eco-Informed Material Choice. 1st Edition, Butterworth Heinemann, Oxford, 129-136, 161-174, 265-365.

[2] Ashby, M.F. and Department of Engineering (2012) CES EduPack 2012. User Guide \& Software, UK Patent of Granta Design Limited, Cambridge.

[3] Ashby, M.F., Coulter, P., Ball, N. and Bream, C. (2009) The CES EduPack Eco Audit Tool. White Paper, University of Cambridge \& Granta Design Ltd., Cambridge.

[4] Caslli Tafaj, S., Elezi, D. and Lamani, E. (2010) An Approach for Eco Design Based on the Materials-Energy Binomial. AKTET, III, 194-201.

[5] Caslli Tafaj, S. (2011) Eco Audit, an Easy and Fast Tool That Helps Eco-Product Design. Environment Applications \& Science, 6, 350-358. http://www.jieas.com/

[6] Mangiarotti, A. and Tronconi, O. (2010) Il Progetto di Fattibilita. McGraw-Hill, Milano.

[7] Hoff, J. (2006) Equivalent Uniform Annual Cost (EUAC): A New Approach to Life Cycles Analyses. Proceedings of the RCI 21st International Convention, Phoenix, 23 March 2006, 115-124.

[8] ERE: Energy Regulatory Entity (2009) The Energy Consumption of Electricity in the Household-The Study, Tirana. 18-21. http://vifon.net/read-file/studimi-konsumi-i-energjise-elektrike-ne-familje-ere-pdf-1474848/

[9] Cengiz, I.A. (2002) Tepe Betopan-Coated, Cement Bonded Wood Particle Boards. AU Patent No. 2002337630.

[10] Voshtina, L., Shtjefni, A. and Alushaj, R. (2002) Technical Physics. Part II: Heating \& Ventilation Buildings. 5th Edition, SHBLU, Tirana, 135-175.

[11] Edition of Official Publication Center (2012) Technical Analysis for Construction Works of Buildings. Official Journal of the Republic of Albania, 83, 3859. http://www.scribd.com/doc/129698232/Manualet-TEKNIKE-VKM-407-27-06-2012-Fl-zyrtare-83-2012

[12] DCA Office of Affordable Housing (2011) Expected Useful Life Table. Architectural Manual. http://www.commerce.wa.gov/Documents/Expected-Useful-Life.pdf 